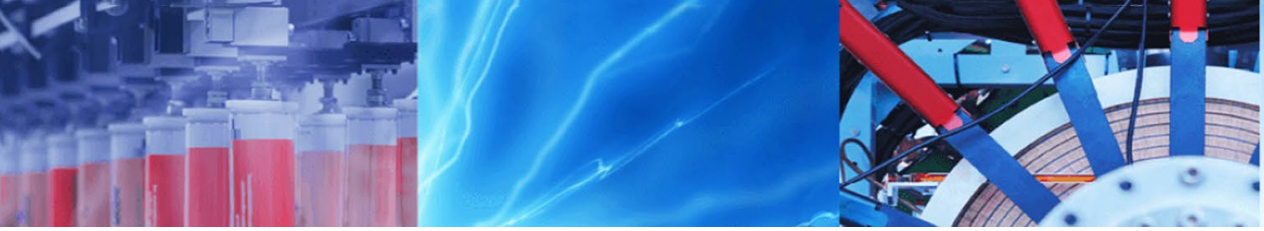

Research Article

\title{
Comprehensive characterization of indigenous lignocellulosic biomass from Northeast India for biofuel production
}

\author{
Yengkhom Disco Singh ${ }^{1}$
}

(c) Springer Nature Switzerland AG 2019

\begin{abstract}
In this study, 18 species of lignocellulosic biomass from Northeast India have been explored to utilize as new feedstock for biofuel production. The biomass sample were examined and characterized proximately and taxonomically for their energy content. The possibility of this lignocellulosic biomass in biofuel production was addressed. A well-documented herbarium specimen based on the morphological features clearly indicating systematic taxon was maintained. The ecological survey and distribution of the plants were applied and found three families, namely poaceae, cyperaceae and typhaceae. Taxonomical ranks were assigned to the collected biomass. Energy content in the form of higher heating value was calculated. The calorific value $(\mathrm{MJ} / \mathrm{kg}$ ) ranged from 7.507 to $14.969 \mathrm{MJ} / \mathrm{kg}$. Our findings show that moisture content was highest in biomass sample Cyrtococcum oxyphyllum (12.55 \pm 0.21$)$ and lowest in Chrysopogon aciculatus $(7.51 \pm 0.25)$. Volatile matter content of biomass varies in the interval of $77.88 \pm 0.20 \%-86.51 \pm 0.27 \%$. Ash content was very less (below 5\%) for the biomass such as Cymbopogon longifolium (4.51 $\pm 0.26 \%)$, Saccharum sponteneum (4.58 $\pm 0.25 \%)$ and Cyrtococcum oxyphyllum (4.70 $\pm 0.10 \%$ ). Dichanthium assimile (Steud.) Deshp. shows the highest cellulose (40.57\%) composition than other species. Minimum cellulose percentage was found in biomass Setaria glauca (24.9\%). In overall, this lignocellulosic biomass can be utilized to produce biofuel as they contained a high percentage of cellulose and hemicellulose with less lignin.
\end{abstract}

Keywords Biofuel $\cdot$ Proximate $\cdot$ Cellulose $\cdot$ Higher heating value $\cdot$ Herbarium $\cdot$ Taxonomical position

\section{Introduction}

Biofuel is a fuel that is produced through biological processes rather than geological processes. It can be derived directly from the plant, animal or microbial biomass. Biomass contains stored energy, which can be used as a source of energy. In essence, solar energy is trapped by the biomass (plants) through the process called photosynthesis. In the process of photosynthesis, light energy is converted into chemical energy that can be later harnessed as fuel. The chemical energy which is fixed or stored in the form of carbohydrate molecules, such as glucose, gets synthesized from carbon dioxide and a water molecule in the plant leaves. The following equation summarizes the overall process of photosynthesis and shows how the molecules are combined together to form the glucose. Biofuel can be produced directly or indirectly from plant biomass through the thermal, chemical or biochemical processes.

$6 \mathrm{CO}_{2}+12 \mathrm{H}_{2} \mathrm{O}+$ Light $\rightarrow \mathrm{C}_{6} \mathrm{H}_{12} \mathrm{O}_{6}+6 \mathrm{H}_{2} \mathrm{O}+6 \mathrm{O}_{2}$

The technologies of biomass conversion to biofuel can be described in two distinct pathways: thermochemical and biochemical processes [1, 2]. The thermochemical conversion, also called as the syngas process, involves controlled heating or oxidation of biomass. The biochemical conversion involves the production of fermentable sugars and their conversion to liquid fuels or gas by microbial population. Both thermochemical and biochemical

$\triangle$ Yengkhom Disco Singh, disco.iitg@gmail.com | ${ }^{1}$ Department of Post Harvest Technology, College of Horticulture and Forestry, Central Agricultural University, Pasighat, Arunachal Pradesh 791 102, India.

SN Applied Sciences (2019) 1:458 | https://doi.org/10.1007/s42452-019-0453-0

Received: 18 March 2019 / Accepted: 4 April 2019 / Published online: 15 April 2019 
technologies are competitive in the calculation of their energy conversion efficiencies.

Biomass energy has many advantages over traditional fossil-based fuels. Most importantly, the issues of global warming due to the accumulation of carbon dioxide in the atmosphere can be minimized. Burning of biomass as well as its derivative fuels in the form of solid, liquid and gaseous fuels (for example charcoal, ethanol and methane) release carbon dioxide into the atmosphere. However, plants also take carbon dioxide out of the atmosphere, so there is no net addition of $\mathrm{CO}_{2}$ [3].

The current scenario of fossil fuels production and its impact on global warming has created the researcher to think on new alternative renewable fuels to be used in the transportation sector. The tradition used of biofuel production mainly depends on the rice, wheat or starchy crops. The biofuel derived from such raw material is called as the first generation of biofuel. However, the problems of food versus fuels led to introduce the second generation of biofuel [4]. The plant biomass-derived fuel seems to be one of the potential alternatives fuel to fossil fuels. This lignocellulosic-derived fuel is considered as the second generation of biofuel.

India contributes around $18 \%$ of the world population next to China. It uses only $6 \%$ of the world's primary energy. Since 2000 , India's energy consumption has almost doubled and the potential for further rapid growth is enormous. The biomass-derived energy is the major source of energy that needs to be developed in large scale in other to fulfill the increasing energy demand. In rural areas of India, this primary fuel is the rural energy economy, of which 840 million people are using as cooking fuel until today. The bioenergy roughly accounts a quarter of India's energy consumption. The production of biofuels needs to be scaled up and, possible technologies could be employed.

The geographical space available for agricultural land in India is around $57 \%$, pasture $3 \%$, woodlands $8 \%$ and the remainder being forest areas or not suitable for cultivation (mountains, deserts, built-up areas). The primary energy demand of India in new policy scenario [5] suggested that in all sector, bioenergy is predicted to increase except the building sector. There is a slow growth of the biofuel energy demand in the transport sector. By considering the current increase in the need for fuel and harmful effect caused by using fossil fuels, bioenergy needs to play the major role.

The Global Agricultural Information Network [6] reported that in India, there are more than 330 ethanol distilleries with an annual production capacity of over 4 billion liters of rectified spirit (alcohol) and 1.5 billion liters of fuel ethanol per year. The current ethanol production level is 2.2 billion liters, and a blending rate of $2.8 \%$ was achieved in 2015. Technically, the current capacity for ethanol production is sufficient to meet around $8 \%$ of blending with gasoline only. This implies to look for exploration of other raw materials like lignocellulosic biomass to achieve the $20 \%$ blending target by 2020 rather than importing from other countries.

The main substrate for the production of ethanol in India is sugarcane molasses a by-product of the sugar industry. The optimal supply of sugar does not match with the demand. Therefore, there is always mismatch production of ethanol from the sugar mill. The obvious consequences of these are large importing of ethanol to India. A potential solution to boost ethanol production on sustainable development is to make use of alternative feedstock. Researchers have paid attention to use lignocellulosic biomass as a potential alternative for ethanol production $[7,8]$.

Northeastern (NE) region of India is situated geographically between $22^{\circ} \mathrm{N}^{\prime}$ and $29^{\circ} 5^{\prime} \mathrm{N}$ latitude and $88^{\circ} 00^{\prime} \mathrm{E}$ and $97^{\circ} 30^{\prime} \mathrm{E}$ longitudes. It covers nearly 262,379 sq. km area. The region comprises seven states (Arunachal Pradesh, Assam, Meghalaya, Manipur, Tripura, Mizoram, Nagaland) which are called as seven sisters of India with extending state Sikkim (Fig. 1) [9]. This region is officially recognized as a special category of Indian states. The region contributes around $7.9 \%$ of the country's total geographical area. The northeast region of India contributes more than onethird of India's total biodiversity. The region harbors one of the most important biodiversity hotspot (Indo-Myanmar biodiversity hotspot) of India out of 25 global biodiversity hotspots recognized. The region is known for its richness biological values having different vegetation types. The $\mathrm{NE}$ region is unique in providing the habitats of different

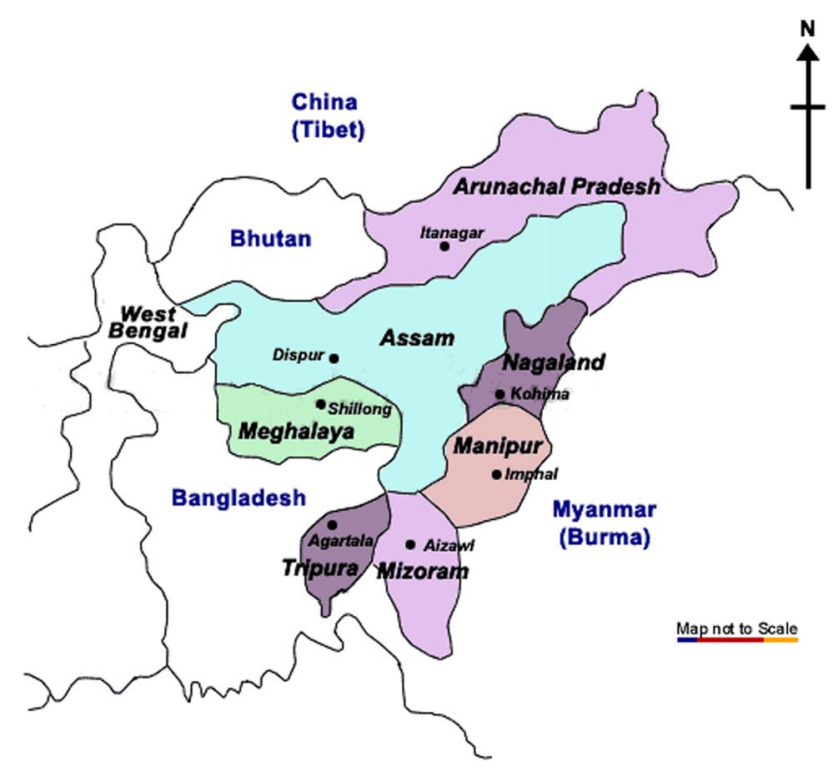

Fig. 1 Northeastern Region and its constituent states in India [9] 
features of biota with a high endemic species. The region is also the abode of different 225 tribes of India, out of 450 tribes in the country with different culture and customs of which have an important role in understanding the biodiversity conservation and management.

Northeastern region of India is unique in terms of availability of huge amount of lignocellulosic biomass (LCB). Many of the biomass species of this region still remain unexplored. Hardly, a few LCB have been explored for bioethanol production from this region of the country. The plant biomass such as Lantana camara, Saccharum sponteneum, Parthenium hysterophorus and Echhornia sp. of the region has been tested for ethanol production to meet the future energy demand [10]. However, the majority of the plant biomass has remained unexplored.

Hence, an attempt is made to explore the high energyyielding plants from this region. Some of the biomass having the potential for biofuel production from this area had been earlier reported [4]. Perhaps, this collected biomass could be a better candidate for future biofuel production. Lignocellulosic biomass such as grasses is one of the dominating plant biomass growing profoundly in hilly terrain areas of this region, and these biomasses can be harnessed to produce bioethanol.

\section{Materials and methods}

In the present study, 18 species of plant biomasses from Northeast India were collected. The collection of the species was done randomly by looking to its different ecological distributions of the plants in a locality. The parameters for biomass to be considered as feedstock such as energy content and carbohydrate content are analyzed. Most importantly, the collected plant biomasses were systematically identified to ensure the correct taxonomical hierarchal position. The geological position of the collected species was recorded. The general outline of the experimental method is given in Fig. 2 .

\subsection{Ecological survey}

The geographical survey of northeast India was performed by visiting the different parts of the region. Before conducting the field trips, the literature review was conducted to learn the geographical stratospheric in the study area.

\subsection{Biomass sample collection}

The biomass sample was collected from northeast India mainly from two states, Assam and Manipur. All the species were collected in full inflorescence stage

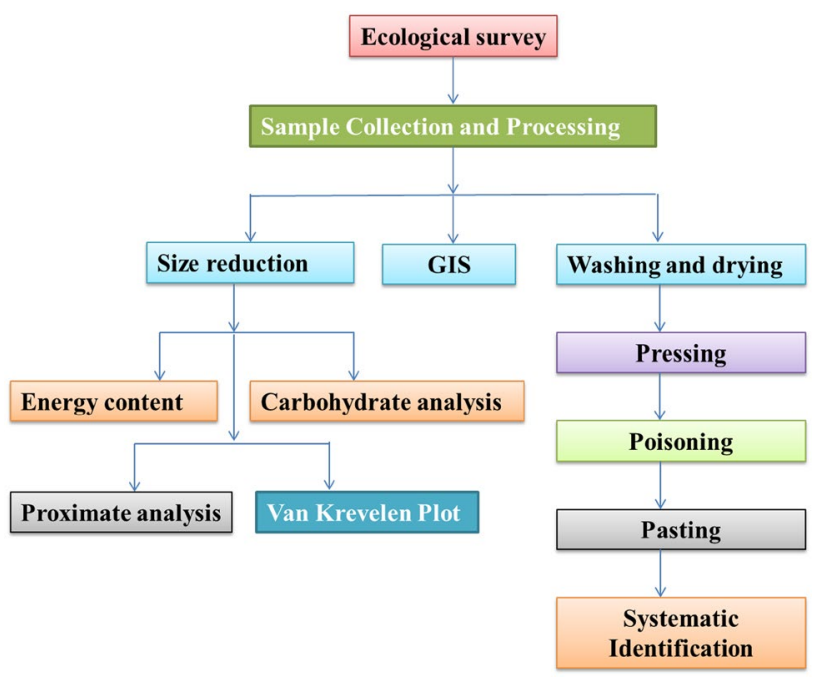

Fig. 2 The general outline of the experimental methods

in order to make easier in the identification process $[4,11]$. Simple tools like scissors, knife, field notebook, high-resolution camera, geographic information system (GIS) tool, gloves, glue and polyethene pack, etc. were used for collection and preparation of the sample. The collected biomass was washed and sun-dried for 10-12 h. The visible sand, soil and other contaminants were removed manually. The biomass was powdered in a mixer grinder to achieve particle size up to $1 \mathrm{~mm}$. The ground biomass powder was stored in a plastic container. The plastic container was made airtight to protect from contamination and further degradation. The latitude and longitude of the collection site of the plants were recorded. A clear photograph of the plants growing in a natural condition for each biomass sample was taken. The experimental data presented are the average of three readings.

\subsection{Herbarium preparation and taxonomical identification}

The herbarium sheets prescribed by the Guwahati University were procured from local market. The collection of the sample was carried out in two different seasons, i.e., summer and winter. The collected sample was washed under running tap water, and the access water was removed with tissue paper carefully. The specimen sample was pressed. The pressed sample was treated for poisoning with $0.03 \%$ mercury chloride. The sample was washed with $70 \%$ ethanol. The poisoned treated specimen was pasted using glue on the herbarium sheet. The specimen was adjusted by cutting the edges while pasting. Two numbers of sheets were made and submitted 
to the Department of Botany, Gauhati University, Assam, for the systematic identification of the plant samples.

\subsection{Energy content of biomass sample}

The energy content of the collected biomass was analyzed as follows [4]. The elemental composition of the biomass sample was determined [4].

Higher heating value (HHV)

$$
\begin{aligned}
=\{ & 33.5 \times \% \mathrm{C}+142.3 \times \% \mathrm{H}-15.4 \\
& \times \% \mathrm{O}-14.5 \times \% \mathrm{~N}\} \times 10^{-2}
\end{aligned}
$$

where $\mathrm{HHV}$ represents the higher heating value and $\mathrm{C}, \mathrm{H}$, $\mathrm{O}, \mathrm{N}$ represents the carbon, hydrogen, oxygen and nitrogen in percentage.

\subsection{Van Krevelen plot}

The derivative plot of the van Krevelen plot was drawn against the atomic ratio of hydrogen $(\mathrm{H})$ : carbon(C) to oxygen (O): carbon (C) [4].

\subsection{Proximate analysis}

The moisture content of the biomass sample was estimated by convection oven dry method [12]. The moisture content was determined as follows:

\subsection{Carbohydrate compositional analysis}

For the estimation of carbohydrate composition in the biomass, the fiber analysis system was conducted using fibra plus automatic fiber estimation system, pelican. The dried and powdered biomass sample of $1 \mathrm{~g}$ was subjected to fibra plus at $400{ }^{\circ} \mathrm{C}$ for $60 \mathrm{~min}$. Neutral detergent fiber (NDF) was determined by taking $1 \mathrm{gm}$ of powdered biomass in a crucible dissolving in NDF solution of 6.9-7.1 pH. The mixture solution was reflux at $400{ }^{\circ} \mathrm{C}$ for $60 \mathrm{~min}$. After the reflux, the refluxed crucible was washed with acetone and kept in an oven at $100^{\circ} \mathrm{C}$ for $8 \mathrm{~h}$. T(2) NDF percentage was calculated [4]. The acid detergent lignin (ADL) was determined by taking the ADF with $72 \%$ of $\mathrm{H}_{2} \mathrm{SO}_{4}$ in a crucible. The mixture was kept for $3 \mathrm{~h}$ with interval stirring. The mixture was filtered, washed and kept in a hot air oven at $100^{\circ} \mathrm{C}$ for $8 \mathrm{~h}$. The weight loss was recorded, and ashing was conducted on the same sample in the muffle furnace at $500{ }^{\circ} \mathrm{C}$ for $7 \mathrm{~min}$. The weight loss was recorded. The percentage of carbohydrate composition such as cellulose, hemicellulose and lignin was calculated accordingly [4, 12].

\section{Results}

\subsection{Ecological survey}

The 18 biomass samples were collected and screened for their fuel content and carbohydrate content. The geo-

$\%$ Moisture $=\left[1-\frac{(\text { Weight dried sample plus dish }- \text { Weight dish })}{(\text { Weight sample as received })}\right] \times 100$

For the total solid calculation,

Total solid $=100-$ moisture $\%$

The total volatile matter was found out according to the ASTM 3175-89 [13]. The calculation is given as follows:

Weight loss, $\%=[(A-B) / A] \times 100$

where $A=$ weight of the sample and $B=$ weight of the sample after heating

Volatile matter in sample, $\%=C-D$

where $C=$ weight loss, $\%$, and $D=$ moisture $\%$.

Ash content was determined by using a muffle furnace $[4,12]$.

The fixed carbon (FC) content was calculated by as far the available empirical formula [14].

$\mathrm{FC}=100-(\%$ of moisture $+\%$ of volatiles $+\%$ of ash $)$ logical positional indication of the collected samples was recorded and presented in Table 1.

\subsection{Biomass sample collection}

The 18 species of biomass sample were collected from different parts of northeast India. The samples were presented in the form of a herbarium specimen. The herbarium specimen was systematically identified by the curator before assigning the voucher number. The herbarium specimen was well characterized, categorized and given taxon for each sample based on the morphological analysis, and specific number for each documents was assigned in the form of voucher number so that in future; this voucher number will be utilized as reference number. A systematic classification of collected plant biomass, voucher number and their location is given in Table 1. 
Table 1 Collected plants of northeast India representing position and voucher number

\begin{tabular}{|c|c|c|c|c|c|c|c|}
\hline SI No. & Class & Order & Family & Genus & Botanical name & Latitude and longitude & Voucher no. \\
\hline 1 & Liliopsida & Poales & Poaceae & Dichanthium & Dichanthium assimile (Steud.) Deshp & $\begin{array}{l}24^{\circ} 28^{\prime} 35.6298^{\prime \prime} \\
94^{\circ} 1^{\prime} 17.7306^{\prime \prime}\end{array}$ & 17737 \\
\hline 2 & Liliopsida & Poales & Poaceae & Cymbopogon & Cymbopogon ambiguus (Hack.) A.Camus & $\begin{array}{l}24^{\circ} 28^{\prime} 35.5944^{\prime \prime} \\
94^{\circ} 1^{\prime} 17.025^{\prime \prime}\end{array}$ & 17733 \\
\hline 3 & Liliopsida & Poales & Poaceae & Arundo & Arundo donax $\mathrm{L}$. & $\begin{array}{l}26^{\circ} 11^{\prime} 15.5256^{\prime \prime} \\
91^{\circ} 41^{\prime} 44.3286^{\prime \prime}\end{array}$ & 17743 \\
\hline 4 & Liliopsida & Poales & Poaceae & Saccharum & Saccharum sponteneum L. & $\begin{array}{l}26^{\circ} 11^{\prime} 1.194^{\prime \prime} \\
91^{\circ} 41^{\prime} 44.3286^{\prime \prime}\end{array}$ & 17741 \\
\hline 5 & Liliopsida & Poales & Poaceae & Cymbopogon & Cymbopogon longifolium & $\begin{array}{l}26^{\circ} 11^{\prime} 21.1236^{\prime \prime} \\
91^{\circ} 41^{\prime} 41.895^{\prime \prime}\end{array}$ & 17734 \\
\hline 6 & Liliopsida & Poales & Poaceae & Setaria & Setaria glauca & $\begin{array}{l}24^{\circ} 29^{\prime} 47.3892^{\prime \prime} \\
94^{\circ} 0^{\prime} 7.578^{\prime \prime}\end{array}$ & 17732 \\
\hline 7 & Liliopsida & Poales & Poaceae & Cynodon & Cynodon dactylon (L.) Pers & $\begin{array}{l}26^{\circ} 11^{\prime} 01.5^{\prime \prime} \mathrm{N} \\
91^{\circ} 41^{\prime} 46.0^{\prime \prime} \mathrm{E}\end{array}$ & 17822 \\
\hline 8 & Liliopsida & Poales & Poaceae & Echinochloa & Echinochloa colonum (L). Link. & $\begin{array}{l}24^{\circ} 28^{\prime} 55.4^{\prime \prime} \mathrm{N} \\
93^{\circ} 59^{\prime} 01.8^{\prime \prime} \mathrm{E}\end{array}$ & 17823 \\
\hline 9 & Liliopsida & Cyperales & Poaceae & Chrysopogon & Chrysopogon aciculatus & $\begin{array}{l}26^{\circ} 14^{\prime} 04.0^{\prime \prime} \mathrm{N} \\
91^{\circ} 57^{\prime} 23.6^{\prime \prime} \mathrm{E}\end{array}$ & 17824 \\
\hline 10 & Liliopsida & Poales & Poaceae & Eleusine & Eleusine indica $\mathrm{L}$. & $\begin{array}{l}24^{\circ} 29^{\prime} 48.9^{\prime \prime} \mathrm{N} \\
94^{\circ} 00^{\prime} 27.9^{\prime \prime} \mathrm{E}\end{array}$ & 17827 \\
\hline 11 & Liliopsida & Cyperales & Cyperaceae & Fimbristylis & Fimbristylis dichotoma Vahl. & $\begin{array}{l}24^{\circ} 29^{\prime} 23.5^{\prime \prime} \mathrm{N} \\
93^{\circ} 59^{\prime} 14.3^{\prime \prime} \mathrm{E}\end{array}$ & 17830 \\
\hline 12 & Liliopsida & Cyperales & Cyperaceae & Cyperus & Cyperus exaltatus Retz. & $\begin{array}{l}24^{\circ} 29^{\prime} 33.6^{\prime \prime} \mathrm{N} \\
93^{\circ} 59^{\prime} 13.9^{\prime \prime} \mathrm{E}\end{array}$ & 17831 \\
\hline 13 & Liliopsida & Poales & Poaceae & Cyrtococcum & Cyrtococcum oxyphyllum (Steud.) Stapf & $\begin{array}{l}24^{\circ} 29^{\prime} 28.5^{\prime \prime} \mathrm{N} \\
93^{\circ} 59^{\prime} 14.6^{\prime \prime} \mathrm{E}\end{array}$ & 17821 \\
\hline 14 & Liliopsida & Poales & Poaceae & Paspalum & Paspalum scrobiculatum L. & $\begin{array}{l}24^{\circ} 29^{\prime} 27.9^{\prime \prime} \mathrm{N} \\
93^{\circ} 59^{\prime} 14.4^{\prime \prime} \mathrm{E}\end{array}$ & 17818 \\
\hline 15 & Liliopsida & Poales & Poaceae & Coix & Coix lacryma-jobi L. & $\begin{array}{l}24^{\circ} 29^{\prime} 17.8^{\prime \prime} \mathrm{N} \\
93^{\circ} 59^{\prime} 08.8^{\prime \prime} \mathrm{E}\end{array}$ & 17816 \\
\hline 16 & Liliopsida & Cyperales & Poaceae & Cyperus & Cyperus alternifolius & $\begin{array}{l}24^{\circ} 29^{\prime} 30.6^{\prime \prime} \mathrm{N} \\
93^{\circ} 59^{\prime} 12.3^{\prime \prime} \mathrm{E}\end{array}$ & 17832 \\
\hline 17 & Liliopsida & Poales & Poaceae & Thysanolena & Thysanolaena maxima (Roxb.) Kuntze & $\begin{array}{l}26^{\circ} 11^{\prime} 15.8^{\prime \prime} \mathrm{N} \\
91^{\circ} 41^{\prime} 45.2^{\prime \prime} \mathrm{E}\end{array}$ & 17817 \\
\hline 18 & Liliopsida & Cyperales & Cyperaceae & Cyperus & Cyperus Flavidus Retz. & $\begin{array}{l}24^{\circ} 29^{\prime} 06.8^{\prime \prime} \mathrm{N} \\
93^{\circ} 59^{\prime} 07.1^{\prime \prime} \mathrm{E}\end{array}$ & 17829 \\
\hline
\end{tabular}

\subsection{Herbarium analysis}

The herbarium sample was deposited to the Postgraduate Department of Botany, Guwahati University, Assam. The binomial nomenclature was given to each specimen stating its taxon name, class, order, family, genus and species (Table 1).

\subsection{Energy content}

The energy content of the biomass samples was calculated as higher heating value (HHV). The data generated are given in Fig. 3. It was observed that the calorific value
$(\mathrm{MJ} / \mathrm{kg}$ ) range from 7.507 to $14.969 \mathrm{MJ} / \mathrm{kg}$ was seen in the selected biomass.

\subsection{Proximate analysis}

The data obtained from proximate analysis (moisture content, volatile matter, ash, fixed carbon content and total solid content) of the biomass samples are presented in Table 2.

\subsection{Van Krevelen plot}

Oxidation of the elements present in the biomass contributes to the burning process. The important elements 


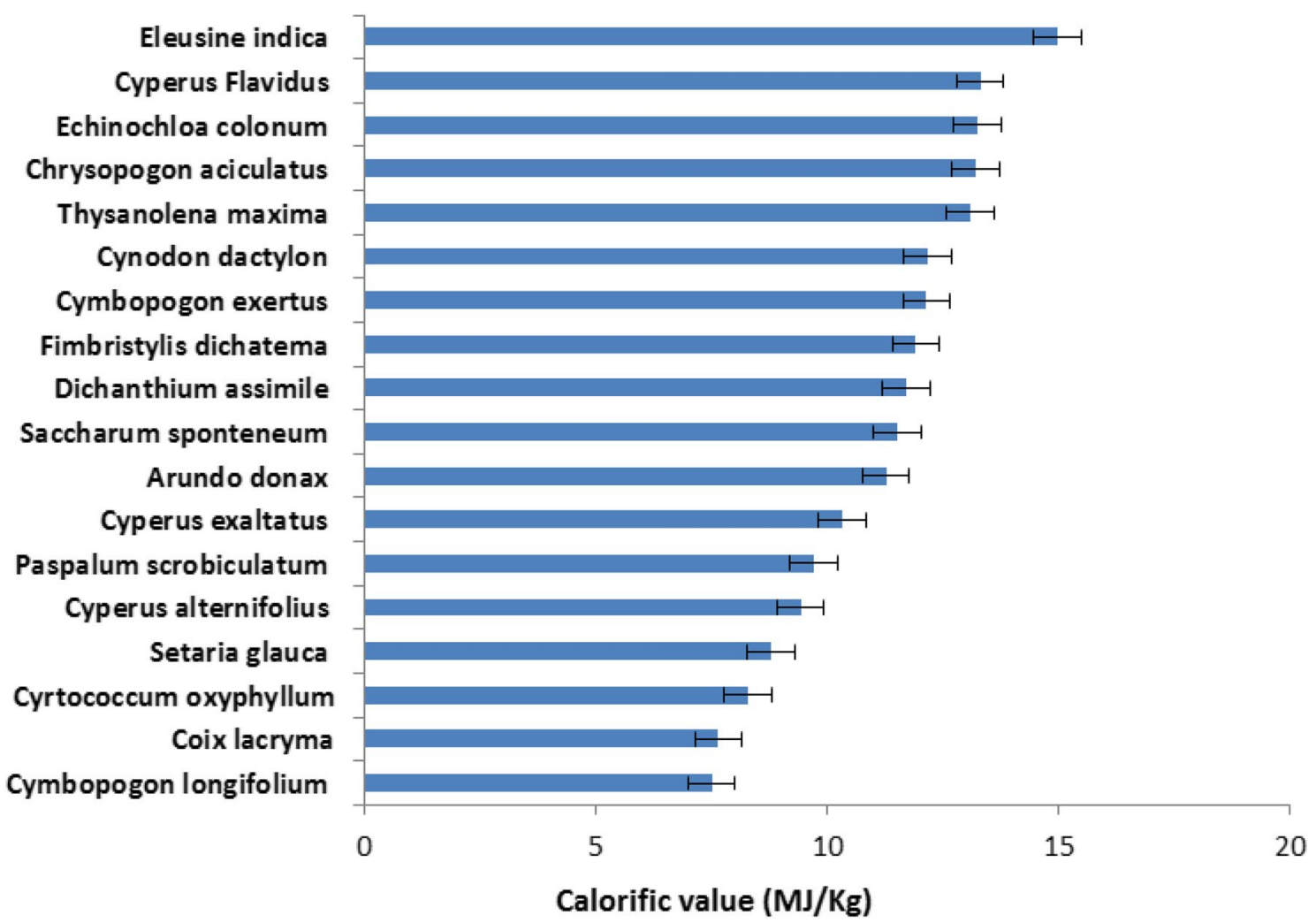

Fig. 3 Energy content of the collected biomass

Table 2 Proximate analysis of different lignocellulosic biomass

\begin{tabular}{|c|c|c|c|c|c|c|}
\hline & Botanical name & Moisture (\%) & Total solid (\%) & Volatile matter (\%) & $\begin{array}{l}\text { Fixed carbon } \\
\text { (\%) }\end{array}$ & Ash (\%) \\
\hline 1 & Dichanthium assimile & $10.56 \pm 0.16$ & 89.63 & $80.91 \pm 0.58$ & 0.46 & $8.07 \pm 0.08$ \\
\hline 2 & Cymbopogon exertus & $8.88 \pm 0.28$ & 90.94 & $84.42 \pm 0.39$ & 0.15 & $6.55 \pm 0.23$ \\
\hline 3 & Arundo donax & $9.76 \pm 0.17$ & 90.023 & $83.19 \pm 0.24$ & 0.73 & $6.32 \pm 0.18$ \\
\hline 4 & Saccharum sponteneum & $7.52 \pm 0.29$ & 92.882 & $84.66 \pm 0.40$ & 3.24 & $4.58 \pm 0.25$ \\
\hline 5 & Cymbopogon longifolium & $9.45 \pm 0.08$ & 90.437 & $84.50 \pm 0.24$ & 1.54 & $4.51 \pm 0.26$ \\
\hline 6 & Setaria glauca & $8.44 \pm 0.19$ & 91.31 & $84.71 \pm 0.66$ & 1.27 & $5.58 \pm 0.29$ \\
\hline 7 & Cynodon dactylon & $8.60 \pm 0.23$ & 91.725 & $86.51 \pm 0.27$ & 1.35 & $3.54 \pm 0.28$ \\
\hline 8 & Echinochloa colonum & $8.40 \pm 0.22$ & 91.331 & $83.62 \pm 0.28$ & 2.55 & $5.43 \pm 0.25$ \\
\hline 9 & Chrysopogon aciculatus & $7.51 \pm 0.25$ & 92.765 & $85.56 \pm 0.23$ & 1.37 & $5.56 \pm 0.21$ \\
\hline 10 & Eleusine indica & $8.53 \pm 0.19$ & 91.438 & $82.56 \pm 0.41$ & 2.5 & $6.41 \pm 0.25$ \\
\hline 11 & Fimbristylis dichotoma & $12.30 \pm 0.30$ & 87.86 & $80.78 \pm 0.63$ & 0.48 & $7.40 \pm 0.22$ \\
\hline 12 & Cyperus exaltatus & $9.42 \pm 0.29$ & 90.156 & $79.83 \pm 0.22$ & 1.92 & $8.83 \pm 0.11$ \\
\hline 13 & Cyrtococcum oxyphyllum & $12.55 \pm 0.21$ & 87.74 & $79.47 \pm 0.27$ & 3.28 & $4.70 \pm 0.10$ \\
\hline 14 & Paspalum scrobiculatum & $7.59 \pm 0.25$ & 92.28 & $82.92 \pm 0.19$ & 1.98 & $7.51 \pm 0.28$ \\
\hline 15 & Coix lacryma-jobi & $9.30 \pm 0.25$ & 90.89 & $79.72 \pm 0.50$ & 0.09 & $11.07 \pm 0.16$ \\
\hline 16 & Cyperus alternifolius & $10.42 \pm 0.24$ & 89.24 & $77.88 \pm 0.20$ & 0.54 & $11.16 \pm 0.44$ \\
\hline 17 & Thysanolena maxima & $9.42 \pm 0.27$ & 90.679 & $81.28 \pm 0.17$ & 0.50 & $8.80 \pm 0.27$ \\
\hline 18 & Cyperus Flavidus & $8.57 \pm 0.28$ & 91.75 & $82.72 \pm 0.58$ & 1.29 & $7.42 \pm 0.19$ \\
\hline
\end{tabular}



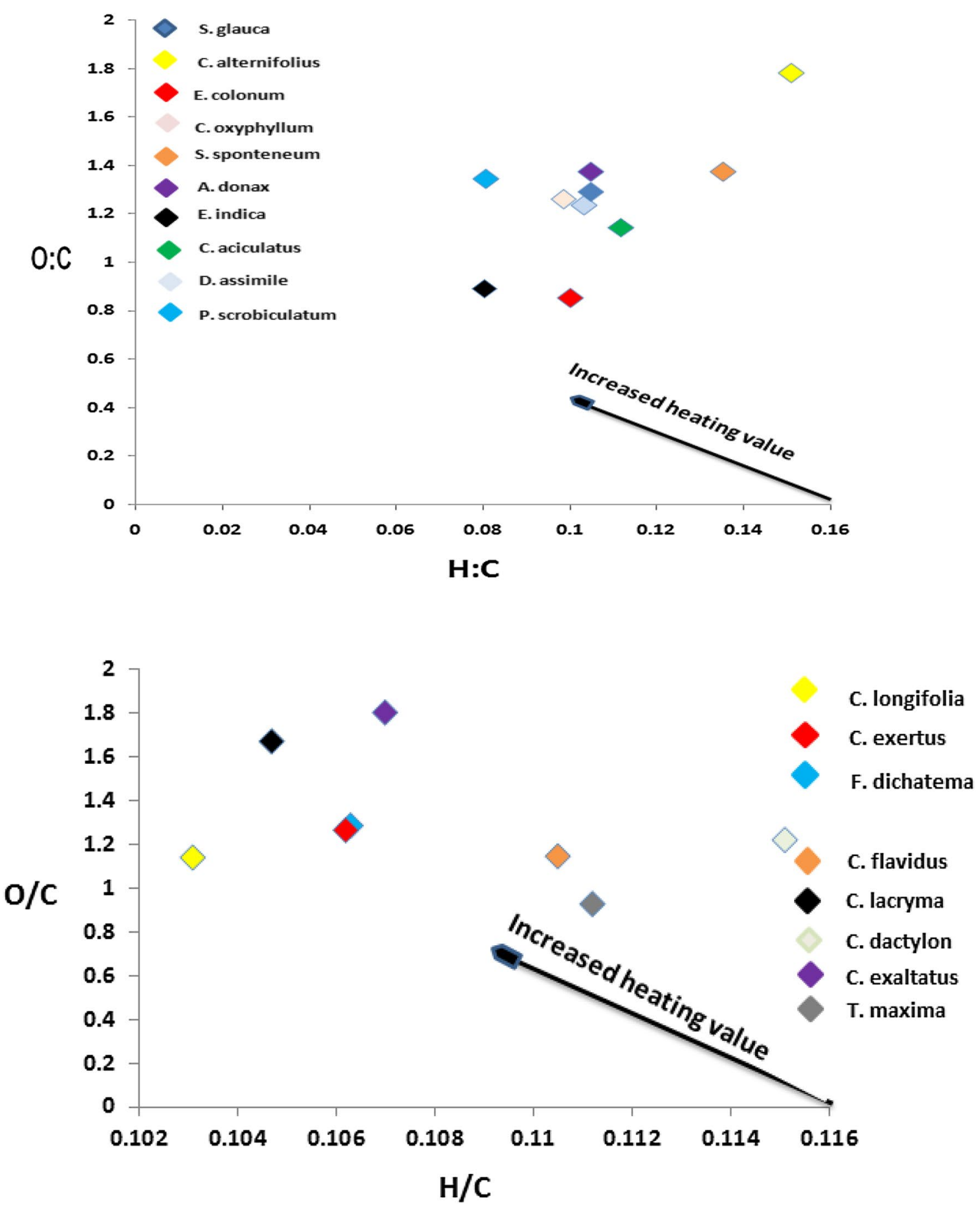

Fig. 4 a, b Van Krevelen plot against the H/C to O/C

consist of carbon, hydrogen, oxygen, nitrogen and sulfur. In 1950, van Krevelen tried to stratify the solid fuels such as biomass in a simple diagram to correlate between the elements by taking ratios such as $\mathrm{H} / \mathrm{C}$ to $\mathrm{O} / \mathrm{C}$. A plot of the van Krevelen diagram was presented in Fig. $4 a$, b.

\subsection{Carbohydrate analysis}

The carbohydrate compositions of the collected biomass are given in Fig. 5. The plant species Dichanthium assimile (Steud.) Deshp. show the highest cellulose (40.57\%) composition than other species. 


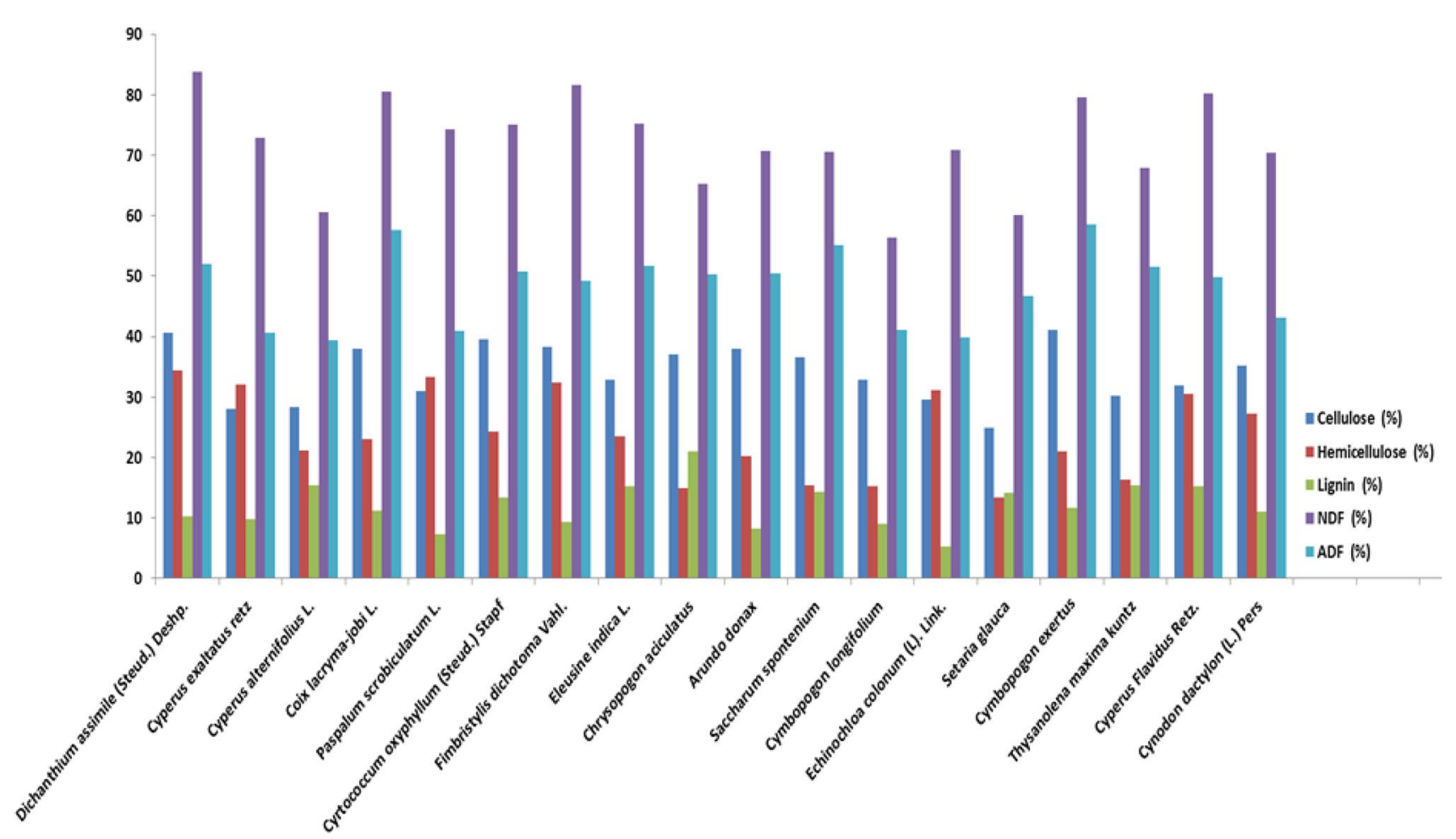

Fig. 5 Carbohydrate compositional analysis of lignocellulosic biomass

\section{Discussion}

Bioethanol is a clean and renewable fuel [15]. It is one of the most important products of industrial biotechnology. At present, sugar-based feedstock such as sugarcane, molasses and starch derivative raw materials such as wheat and corn are primary source of feedstock used to produce bioethanol. It seems that those countries, which have significant agronomic-based economy or agricultural work for their livelihood, have greater advantages to incorporate currently available technology for fuel ethanol production. It is being said that the production of ethanol will be totally based on the biomass available to a locality. Therefore, it is very important to know about the plants which are locally available and show a promising candidate for energy content. The best option to propose a new feedstock is to explore taxonomically new plants confined to a certain locality. That is the reason why we have analyzed the full context of biodiversity of this particular region.

Biodiversity is a general term which refers to the variability among living organisms of a particular habitat. This includes diversity within species, between species and of ecosystems. The difference in biodiversity from region to region is due to variable environmental gradients like latitude, altitude, depth, aridity, etc. Inventorying and monitoring of biodiversity is as important as the species. Hence, the core areas of biodiversity for exploration of new species are taxonomy, genetics and ecology. Taxonomy provides the systematic position of a particular species and reference system. Therefore, an ecological survey was conducted for the regions to have knowledge on the different biogeographical aspect. Ecology provides knowledge of the varied ecological systems in which taxonomic and genetic diversity is located, and of which it provides the functional components. So, a thorough study about the ecological survey was the need of the experimental test. Hence, an ecological survey was conducted in the region.

In this study, 18 species of phytomass from northeast India were collected and characterized. All the collected plant species fall into two families, i.e., poaceae, and cyperaceae. Majority of the plant species collected belonged to poaceae family. Out of 18 species, 5 were cyperaceae and 13 were poaceae (Table 1). The selection of the biomass was done based on the quadrate analysis of the species and was depended on the random selection, abundance and availability of the species to the locality. Since a proper identification of the collected plant sample was highly needed, so the entire specimen was made herbarium and got deposited to the herbarium unit of Guwahati University for future references. The collection of the grasses 
was done in two seasons (summer and winter), as the grasses showed different flowering time due to ecological adaptability variations and morphological characters dissimilatory.

Grasses covered the one-fifth of the Earth's land surface area. It occurs virtually in every terrestrial habitat [16]. According to the Ecological Society of America, grassland is a community dominated by grasses or grass-like plants. The grassland occurs in temperate zones where rainfall varies from 25 to $80 \mathrm{~cm}$, while in tropics region, they may found rainfall up to $150 \mathrm{~cm}$. The favorable conditions for the development of stable and profound grassland are frequent rainfall and warm weather during the growing season. This may be the one reason why northeast India is profoundly covered with grasses.

The grass family which comes under the Poaceae family contributes approximately 11,000 species of 700 genera [17]. In India, there are about 1300 grass species distributed in 25 tribes and 263 genera out of 17,500 known flowering plants [18]. As far as northeast India is concerned, many researchers have worked out in the grass species with their economical viable [19].

Herbaria are the data deposition of particular plants which contained remarkable and irreplaceable sources of information about the plants and the world they inhabit [20]. They provide complete information that is required for scientific studies of taxonomy, systematics classification, ecology, anatomy, morphology, conservation biology, biodiversity, ethnobotany and paleobiology. The most important part of maintaining herbaria is it can be accessible to the public and research communities. The unique number (voucher number) for each specimen was assigned to the herbaria to make the reference easier. The site of the collection in the form of latitude and longitude was also recorded to sure the availability of the plant specimen in future references (Table 1).

The biomass fuels are characterized and classified by the term proximate which gives moisture content, volatile content, ash content, heating value and free carbon. This analysis gives the preliminary idea of fuel energy present in the biomass sample in the form of physical and elemental composition [21]. It is one of the key factors for fuel analysis before going to the end products of fuel generation. The fuel efficacy of the biomass sample is related to moisture content. Moisture content on a dry basis could be calculated as follows

$\mathrm{MCd}=m_{\mathrm{h} 20} / m_{\mathrm{d}}$

where $\mathrm{MCd}=$ moisture content on a dry basis, $m_{\mathrm{h} 20}=$ mass of water $(\mathrm{kg}, \mathrm{lb}), m_{\mathrm{d}}=$ total mass of the dry solids in the sample $(\mathrm{kg}, \mathrm{lb})$.

The moisture content of a biomass sample expresses as the quantity of water per unit mass of the dry sample. We have followed the conventional oven drying method for moisture determination to constant weight at $105^{\circ} \mathrm{C}$. Prolonged drying more than $4 \mathrm{~h}$ was avoided as it can result in loss of volatile matter due to decomposition, distillation or oxidation of the biomass sample. The moisture content may change during handling of the sample, as the dry biomass materials are hygroscopic in nature. High moisture content decreases the combustion yield of biomass [21]. Our findings show that moisture content was highest in biomass sample Cyrtococcum oxyphyllum (12.55 \pm 0.21$)$ and lowest in Chrysopogon aciculatus $(7.51 \pm 0.25)$. In most of the biomass, the moisture content was near to $7-13 \%$ (Table 2). The moisture percentage was calculated on the dry weight basis of the biomass sample. This is the main reason why our selected biomass shows less moisture content. Some of the biomass has a very close similarity of moisture percentage such as Setaria glauca $(8.44 \pm 0.19 \%)$, Cynodon dactylon ( $8.60 \pm 0.23 \%)$ and Echinochloa colonum $(8.40 \pm 0.22 \%)$ as compared with other reported studies [22].

All the biomass used in the production of biofuel needs a typical degree of particle size reduction. Different techniques could apply to reduce the size until it reaches a small size enough to pass through the selected screen size. For the ethanol production from biomass, it usually verified at the range of $\sim 1$ to $6 \mathrm{~mm}$. The characters such as moisture content, bulk density, true density and particle size are important for downstream processing of different kinds of biomass [23]. The comprehensive knowledge for biomass size reduction and size of the particle would provide the best suitable types of equipment for the material to be screened, decreased operating costs and aid in the predictable delivery of uniform size of biomass for processing and conversion.

Processing and size reduction of biomass prior to characterization are a very important aspect. The ground biomass sample was passed through the screen of sieve $(1.18 \mathrm{~mm})$. The particles unable to pass through sieve were regarded as oversized, while those passing through the sieve were used in the characterization. The particle size affects the thermochemical system of the sample $[24,25]$. We fixed our biomass sample to a minimum particle size.

Volatile matter refers to the part of the biomass that is released when the biomass is heated at $925 \pm 10^{\circ} \mathrm{C}$ for $7 \mathrm{~min}$. During this heating process, the biomass decomposed into gases and left out as char. Biomass typically has a high volatile matter than coal (less than $20 \%$ ). The presence of volatile matter in biomass influences the fuel reactivity [26]. Volatile matter content in biomass varies in the interval of $79.47 \pm 0.27 \%-86.51 \pm 0.27 \%$ (Table 2). For example, the plant biomass like Saccharum sponteneum, Dichanthium assimile, Arundo donax, Thysanolena maxima has $84.66 \pm 0.40 \%, 80.91 \pm 0.58 \%, 83.19 \pm 0.24 \%$, 
and $81.28 \pm 0.17 \%$, respectively. The biomass like Cymbopogon exertus ( $84.42 \pm 0.39 \%)$, Saccharum sponteneum (84.66 $\pm 0.40 \%)$, Cymbopogon longifolium (84.50 $\pm 0.24 \%)$, Setaria glauca $(84.71 \pm 0.66 \%)$ has very close similarities.

The ash content is one of the most studied characters of biomass. Ash consists of the mineral matter and inorganic matter [27]. The solid residue of biomass fuel when produced by thermochemical conversion at $575 \pm 10^{\circ} \mathrm{C}$ for $3 \mathrm{~h}$ is called ash. It is an integral part of plant material with a wide range of elements. Ash content affects the combustion rate in the biomass sample. The percentage value varies according to the type of biomass. For example, $0.5 \%$ in wood, $5-10 \%$ in agricultural crops and $30-40 \%$ in rice husk. From our findings, the ash percentage was found the maximum in Cyperus alternifolius $(11.16 \pm 0.44 \%)$ and minimum in Cynodon dactylon (3.54 $\pm 0.28 \%$ ) (Table 2). It can be observed that some biomass sample has very less ash content below 6\% such as Cymbopogon longifolium, Setaria glauca, Echinochloa colonum, Chrysopogon aciculatus, Cyrtococcum oxyphyllum, Saccharum sponteneum, respectively. The variation in ash content was visible in our selected biomass because the biomass has various types of inorganic elements.

Fixed carbon content is the biomass remaining after the release of volatile matter, excluding the ash and moisture content. This differs from the ultimate carbon content of the biomass sample in the fact that the carbon loss took place in the form of hydrocarbon with the volatile matter. It also related to ash, volatile and moisture content of the biomass. The volatile matter and fixed carbon influenced the biological conversion process of the fuel [27]. Woody biomass has much higher fixed carbon content as compared to LCB. The fixed carbon content varies in the interval of $0.09-3.28 \%$ (Table 2). The total solid content was determined by subtracting the moisture percentage from the biomass [28]. The maximum and minimum total solid content was seen in Saccharum sponteneum (92.882\%) and Cyrtococcum oxyphyllum (87.74\%).

The calorific value of a biomass sample is one of the most important characteristics of a fuel. It is useful in planning and control of the combustion plants. It refers to the amount of heat generated from the biomass (weight) during complete combustion in the presence of oxygen. There are two types of calorific value (expressed in $\mathrm{kcal} / \mathrm{kg}$ or $\mathrm{MJ} /$ $\mathrm{kg}$ ): higher heating value (HHV) and lower heating value (LHV). The heating value of any fuel is the energy released per unit of mass per unit volume of the fuel when it completely burned [29]. The higher heating value (HHV) refers to the condition where water is condensed out of the combustion products. HHV is called a gross calorific value. The high heating value can be determined experimentally in the laboratory with an adiabatic calorimeter. The lower heating value (LHV) refers to the condition where water vapors remain in the combustion product, i.e., the steam is not condensed out, and thus, latent heat does not account for. In this study, HHV based on the elemental composition of the biomass was calculated using the available empirical formula [30]. The interval of 7.507-14.969 MJ/kg was seen in the selected biomass (Fig. 3).

Biomass energy is one of the alternative renewable energy that can be a replacement for fossil fuels. The biomass fuel efficacy does not depend on the proximate and ultimate analysis, but also on the atomic ratio of $\mathrm{H} / \mathrm{C}$ and $\mathrm{O} / \mathrm{C}$. A plot of van Krevelen diagram was drawn based on the atomic ratio of hydrogen to carbon and oxygen to carbon. The correlation between hydrogen/carbon $(\mathrm{H} / \mathrm{C})$ and oxygen/carbon $(\mathrm{O} / \mathrm{C})$ ratios was used to locate the biomass sample in the van Krevelen diagram (Fig. 4a, b). The lower the ratio, the higher is the energy content. The material with a relatively low $\mathrm{O} / \mathrm{C}$ ratio has more energy density and higher HHV. This is because there is more chemical energy in $\mathrm{C}-\mathrm{C}$ bonds than in $\mathrm{C}-\mathrm{O}$ bonds. The selected biomass Eleusine indica $\mathrm{L}$. has higher heating value (14.969 MJ/ kg) (Fig. 4a) than other selected biomass. From the van Krevelen diagram, it is well illustrated that Eleusine indica L. has high calorific value than other feedstocks, which was further explained by using the Demirba's formula for HHV. This diagram indicates the co-relation between the calorific value and atomic ratio.

One of the most concerned parameters for biomass fuel analysis is its compositional analysis, which comprises cellulose, hemicellulose and lignin. LCB feedstocks are primarily composed of carbohydrate polymer and lower concentration of proteins, acids, salts and minerals. Cellulose and hemicellulose are polysaccharides that can be hydrolyzed to monomeric sugars and can be used in ethanol fermentation. The ethanol yield from biomass is directly related to cellulose, hemicellulose and other sugars concentration present in the feedstock. Lignin concentration in the biomass is an obstacle to the entire process as it forms a barrier in microbe fermentation; however, it may be useful for other purposes. The content of carbohydrate polymers differs according to the type of feedstock. For example, switchgrass has cellulose (37\%), hemicellulose (29\%) and lignin (19\%). In corn stover, it is about cellulose (38\%), hemicellulose (26\%) and lignin (19\%). Similarly, in wheat straw, it is about cellulose (38\%), hemicellulose (29\%) and lignin (15\%) [26, 31].

From our finding, the biomass Dichanthium assimile (Steud.) Deshp has maximum cellulose content. It contributes cellulose $(40.57 \%)$, hemicellulose (34.39\%), lignin (10.3\%), NDF (83.84\%) and ADF (52.08\%). The minimum cellulose content was found in biomass Setaria glauca. It contributes cellulose (24.9\%), hemicellulose (13.31\%), lignin (14.17\%), NDF (60.05\%) and NDF (46.74\%) (Fig. 5). The highest percentage of hemicellulose was seen in 
biomass Dichanthium assimile (34.39\%). In overall, the hemicellulose and lignin percentage were very much low in comparison with cellulose percentage.

The NDF, ADF and ADL were determined based on the detergent fiber analysis (DFA). DFA directly detects the structural component of the biomass sample, which give cellulose, hemicellulose and lignin percentage. The highest NDF recorded was in Dichanthium assimile (83.84\%), and the lowest was in Cymbopogon longifolium (56.30\%) (Fig. 5)

\section{Conclusion}

Biofuel production from the second generation of biomass is one of the emerging areas. However, due to the fact that shortage of feedstock in sustainable production of biofuel will affect the fuel demand, therefore, it is highly important to explore a new type of raw material to check the fuel sustainably. To overcome this problem, the experiments were conducted and an attempt is made to explore new raw materials taxonomically available in northeast India for biofuel generation. All the collected species may be used as feedstock for biofuel production. The explored 18 species were highly indigenous to this region. All the parameters like the energy content of the biomass, carbohydrate composition and proximate analysis reveal that this biomass could be a potential feedstock for biofuel production. Dichanthium assimile (Steud.) Deshp showed the highest percentage of cellulose component. The high energy content was found in all biomass samples showing positive potential for biofuel production.

Acknowledgements The author is thankful to IIT Guwahati, center for energy and CHF Pasighat, for providing the facilities.

\section{Compliance with ethical standards}

Conflict of interest The authors declare no conflict of interest. Mentioning trade names or commercial products in this paper is solely for the purpose of providing specific information and does not imply recommendation or endorsement by the authors.

\section{References}

1. Menon V, Rao M (2012) Trends in bioconversion of lignocellulose: biofuels, platform chemicals \& biorefinery concept. Prog Energy Combust Sci 38(4):522-550

2. Nanda S, Mohammad J, Reddy SN, Kozinski JA, Dalai AK (2014) Pathways of lignocellulosic biomass conversion to renewable fuels. Biomass Convers Biorefin 4:157-191

3. Tasneem A, Abbasi SA (2010) Biomass energy and the environmental impacts associated with its production and utilization. Renew Sustain Energy Rev 14:919-937. https://doi. org/10.1016/j.rser.2009.11.006

4. Singh YD, Mahanta P, Bora U (2017) Comprehensive characterization of lignocellulosic biomass through proximate, ultimate and compositional analysis for bioenergy production. Renew Energy 103(2017):490-500. https://doi.org/10.1016/j.renen e.2016.11.039

5. International Energy Agency (2015) Renewable information 2015. https://www.iea.org/newsroom/news/2015/

6. Global Agricultural Information Network (GAIN) report 2014, number: IN4055 https://www.fas.usda.gov/data

7. Venkatesh B (2014) Current challenges in commercially producing biofuels from lignocellulosic biomass. Int Sch Res Not 31. http://dx.doi.org/10.1155/2014/463074

8. Anuj KC, Lakshmi MN, Chandrasekhar G, Manikyam A, Venkateswar LR (2009) Use of Saccharum spontaneum (wild sugarcane) as biomaterial for cell immobilization and modulated ethanol production by thermotolerant Saccharomyces cerevisiae VS3. Biores Technol 100:2404-2410. https://doi.org/10.1016/j. biortech.2008.11.014

9. http://www.iitg.ac.in/rcilts/phasel/ne.html. Accessed 9 Apr 2019

10. Mohan SSDT, Amol D, Sanjeeva RD, Arjuna VRP, Uttam AG, Rao VY, Rao VB, Subba VRM (2016) Bioethanol production through separate hydrolysis and fermentation of Parthenium hysterophorus biomass. Renew Energy 86:1317-1323. https://doi. org/10.1016/j.renene.2015.09.074

11. https://www.floridamuseum.ufl.edu/herbarium/voucher.htm. Accessed 19 Feb 2019

12. Sluiter B, Hames D, Hyman C, Payne R, Ruiz C, Scarlata J, Sluiter D, Templeton JW (2008) Determination of total solids in biomass and total dissolved solid in liquid process samples laboratory analytical procedure (LAP) NREL/TP-510-42622, Determination of ash in biomass: Laboratory analytical procedure, January 2008. https://www.nrel.gov/docs/gen/fy08/42620.pdf

13. ASTM D 3175-89 (1989) Standards test method for volatile matter in the analysis sample of coal and coke, in gaseous fuels, coal and coke. Section 5 (5):305. https://www.astm.org/BOOKSTORE/ BOS/TOCS 2015/05.06.html

14. Pazó JA, Granada E, Saavedra A, Patiño D, Collazo J (2010) Heterogenic solid biofuel sampling methodology and uncertainty associated with prompt analysis. Int J Mol Sci 11:2118-2133. https://doi.org/10.3390/ijms11052118

15. Ping W, Cheng Li-Hua, Lin Z, Xin-Hua X, Huan-lin C, Cong-jie G (2013) A review of membrane technology for bioethanol production. Renew Sustain Energy Rev 30:388-400. https://doi. org/10.1016/j.rser.2013.10.017

16. Shantz HL (1954) The place of grasslands in the earth's cover of vegetation. Ecology 35:143-145. https://doi.org/10.2307/19311 10

17. Chen S, Li D, Zhu G, Wu Z, Lu S, Liu L, Wang Z, Sun B et al. (2006) Flora of China. Volume XII. St. Louis: Science Press, Beijing, and Missouri Botanical Garden Press. Poaceae, pp 1-651. http://flora .huh.harvard.edu/china/mss/volume12/index.htm

18. Nair VJ, Murthy GVS (2012) Bibliography of Indian Poaceae. Botanical Survey of India 223, Kolkata. https://bsi.gov.in/Archi ve/10_2_Archive.aspx

19. Chowdhury S (ed) (2005) Assam's Flora-present status of vascular plants. Assam Science Technology and Environment Council, Guwahati. https://trove.nla.gov.au/version/177684205

20. Dalton R (2003) Natural history collections in crisis as funding is slashed. Nature 423:575

21. García R, Pizarro C, Lavín AG, Bueno JL (2013) Biomass proximate analysis using thermogravimetry. Biores Technol 139:1-4. https ://doi.org/10.1016/j.biortech.2013.03.197

22. Sudhagar M, Lope GT, Shahab S (2006) Effects of compressive force, particle size and moisture content on mechanical 
properties of biomass pellets from grasses. Biomass Bioenergy 30(7):648-654

23. Ebling JM, Jenkins BM (1985) Physical and chemical properties of biomass fuels. Trans ASAE 28(3):898-902

24. Bergman PCA, Boersma AR, Kiel JHA, Prins MJ, Ptasinski KJ, Janssen FJJG (2005) Torrefaction for entrained-flow gasification of biomass, ECN-C-05-067, ECN: Petten, The Netherlands. https:// www.ecn.nl/docs/library/report/2005/c05067.pdf

25. Lu Y, Wang Y, Xu G, Chu J, Zhuang Y, Zhang S (2010) Influence of high solid concentration on enzymatic hydrolysis and fermentation of steam-exploded corn stover biomass. Appl Biochem Biotechnol 160:360-369. https://doi.org/10.1007/s1201 0-008-8306-0

26. McKendry P (2002) Energy production from biomass (part 1): overview of biomass. Biores Technol 83:37-46. https://doi. org/10.1016/S0960-8524(01)00118-3

27. Vassilev SV, Baxter D, Andersen LK, Vassileva CG (2010) An overview of the chemical composition of biomass. Fuel 89:913-933. https://doi.org/10.1016/j.fuel.2009.10.022
28. Technical Report NREL/TP-510-42621. https://www.nrel.gov/ docs/gen/fy08/42621.pdf

29. St. Joseph (2011) ASABE Standards, American Society for Agricultural \& Biological Engineers, MI: ASABE. https://elibrary.asabe .org/standards.asp

30. Demirbas A (1997) Calculation of higher heating values of biomass fuels. Fuel 6:431-434. https://doi.org/10.1016/S0016 -2361(97)85520-2

31. Zheng Y, Zhao J, Xu F, Li Y (2014) Pretreatment of lignocellulosic biomass for enhanced biogas production. Prog Energy Combust Sci 42:35-53. https://doi.org/10.1016/j.pecs.2014.01.001

Publisher's Note Springer Nature remains neutral with regard to jurisdictional claims in published maps and institutional affiliations. 